\title{
Recent changes in the climate-growth response of European larch (Larix decidua Mill.) in the Polish Sudetes
}

\author{
Małgorzata Danek ${ }^{1}$ (D) $\cdot$ Tomasz Danek $^{2}$ (D)
}

Received: 6 August 2021 / Accepted: 29 November 2021 / Published online: 9 December 2021

(c) The Author(s) 2021

\begin{abstract}
Key message Recently observed temporal changes in the climate-growth relationship of larch in the Polish Sudetes suggest growth limitations in the future.

Abstract Larches in the Sudetes are very sensitive to the currently changing climatic factors, and an extreme negative response to drought is observed. In this study, temporal changes in the climate-growth relationship of European larch were analyzed using moving-window correlation. Change-point detection analysis was performed to determine whether there is a temporal connection between tree-ring growth responses and changes in climatic factors trends. The Random Forest predictor importance determination method was used to establish the set of climatic factors that influence larch tree-ring growth the most and to show how this set changes over time. Additionally, cluster analysis was applied to find spatial growth patterns and to generalize the growth response of larch. The results indicate that the main clustering factor is altitude. Nevertheless, an increasing unification of the larch's response to dominant climatic factors is observable throughout the whole study area. This unification is expressed in the increasingly positive and recently dominant effect of May temperature. A progressively negative influence of the temperature in the summer and late autumn of the year preceding growth was observed, as was an increasing influence of water availability in the summer months. The study indicates that there is a connection between the observed changes and the recent rapid rise in temperature, which has consequently had a negative influence on water availability. The growth of this tree species in the Sudetes is expected to be very limited in the future due to its sensitivity to drought, the predicted increase in temperatures and thermal extremes, and the decrease of the share of summer precipitation in the annual total.
\end{abstract}

Keywords Climate change $\cdot$ Mountain forest $\cdot$ Climate response $\cdot$ Tree rings $\cdot$ Temperature $\cdot$ Water availability

\section{Introduction}

The vulnerability of mountain forest environments to climate change and global warming is widely studied to predict possible changes and prepare long-term forest management strategies for the future (Beniston 2003; Thompson et al.

Communicated by E. Liang.

Małgorzata Danek mdanek@agh.edu.pl

1 Department of Environmental Analysis, Mapping and Economic Geology, AGH University of Science and Technology, Kraków, Poland

2 Department of Geoinformatics and Applied Computer Science, AGH University of Science and Technology, Kraków, Poland
2009; Lindner et al. 2010, 2014). Varying responses of mountain forest communities have been observed, including disturbances, species distribution, mortality, and growth, and forecasts have been made (e.g., Spiecker 1999; Dale et al. 2001; Allen et al. 2010; Gottfried et al. 2012; Hanewinkel et al. 2013; Rigling et al. 2013; Dyderski et al. 2018). The response of tree growth to climate forcing can be affected by many factors, such as species (e.g., drought-sensitive vs. more drought-tolerant species; see Friedrichs et al. 2009; Eilmann and Rigling 2012; García-Cervigón et al. 2012; Lyu et al. 2017; Du et al. 2020) or site conditions (e.g., elevation and slope aspect: Villalba et al. 1997; Latte et al. 2015; depth to permafrost: Driscoll et al. 2005), which can change over time. Temporal instabilities have been recorded in recent decades (e.g., Briffa et al. 1998; Lebourgeois et al. 2012), which have been expressed as either a weakening or a strengthening of the response of trees to certain climatic 
stimuli (e.g., Carrer and Urbinati 2006; Ponocná et al. 2016; Kolář et al. 2017). For example, for larches in the Italian Alps, a loss of the June temperature signal and an increasing importance of August and May temperatures were observed recently (Coppola et al. 2012). Most studies suggest that altitude is one of the most important factors that differentiate the spatio-temporal pattern of vegetation responses (Jolly et al. 2005), including tree growth (Mäkinen et al. 2002; Babst et al. 2013). As the growth of trees at high altitudes in Central Europe is mainly determined by temperature (e.g., Tessier et al. 1997; Frank and Esper 2005; Leal et al. 2007), the recently observed rising temperatures positively affect tree growth (e.g., Coppola et al. 2012; Ponocná et al. 2016; Rozenberg et al. 2020). However, at lower altitudes, where moisture conditions are generally becoming more important (Mäkinen et al. 2002; Leal et al. 2007; Babst et al. 2013), the negative effects of increasing temperatures, which are related to summer droughts, are observable (e.g., Ponocná et al. 2016; Kolár et al. 2017; Rozenberg et al. 2020).

The Sudetes is a medium-elevated mountain range in Central Europe. An increase in air temperature (a major feature of climate change) that is particularly strong in the mid-latitudes of the northern hemisphere (Hartmann et al. 2013; Ji et al. 2014) is observed throughout the entire altitudinal profile of the Sudetes (e.g., Głowicki 2008; Błażejczyk 2019). For the Karkonosze mountain range, which is the highest part of the Sudetes, the significant trend in mean annual temperature changes was assessed to be about $0.3{ }^{\circ} \mathrm{C}$ per 10 years (Błażejczyk 2019). However, although changes in yearly precipitation for Poland and the Sudetes are not statistically significant (Błażejczyk 2019; Szwed 2019; Ziernicka-Wojtaszek and Kopcińska 2020), a negative trend in the share of summer precipitation has recently been noticed (Ziernicka-Wojtaszek and Kopcińska 2020), with further decreases predicted in the future (Szwed 2019). Additionally, similarly to other areas of Central Europe, changes in the frequency, intensity, and duration of extreme weather conditions have been reported, as has an intensification of summer thermal extremes (Głowicki 2008; Tomczyk and Bednorz 2016; Graczyk et al. 2017; Wypych et al. 2017).

Even in the absence of clear precipitation trends, the positive trend in average temperatures results in increased evapotranspiration (Łabędzki et al. 2011), due to which plants' water requirements increase (Oberhuber et al. 2015). Additionally, the increasing frequency of summer temperature extremes and the duration of heat waves in Central Europe (Tomczyk and Bednorz 2016), which are typically associated with droughts, impair many tree functions (e.g., photosynthesis, photorespiration etc.) and increase the risk of hydraulic failure and carbon starvation, resulting in reduced growth and increased mortality (McDowell et al. 2008; Teskey et al. 2015). On the other hand, the observed temperature increase may have a positive effect on tree growth as long as adequate water resources are available. This is particularly true at high altitudes, where vegetation is generally not limited by water shortages (Ponocná et al. 2016). However, even at high altitudes, further warming can lead to a threshold response, when a decrease in growth and an increase in mortality are observed due to insufficient moisture caused by excessively high temperatures (Lu et al. 2021). Larch (Larix decidua Mill.) is considered one of the most important tree species in the forests of Europe (Dyderski et al. 2018). It is valued for its high-quality wood and fast growth; it is a species that is widely cultivated, even outside of its natural range (Krzysik 1978; Einspahr et al. 1984). Larch represents the seventh largest volume among forest tree species in Europe. Moreover, the biomass of this species can be underestimated (Jagodziński et al. 2018). Although the largest area of its natural occurrence is the Alps, where it is mainly found at high altitudes, it occurs in other regions of Europe and at lower altitudes. This is the case in the Sudetes, where it is an admixture tree species (growing mainly with beech, fir, and spruce) in the forests of the foothills and the lower montane zone. It should be added that the occurrence of larch in the Sudetes is largely the result of cultivation. As with other trees that grow in high mountain locations in Europe, the growth of larch is positively related to temperature, especially in the late spring and summer (e.g., Frank and Esper 2005; Büntgen et al. 2007), and is not limited by precipitation. However, under the conditions of dry alpine valleys, its physiologically conditioned sensitivity to drought (Anfodillo et al. 1998), which is relatively high when compared to other species, becomes clearly visible (Elimann and Rigling 2012). Studies conducted in the Sudetes and the Carpathians, where larch occurs at relatively low altitudes, found that the temperature at the beginning of the growing season (May) had a positive effect on larch growth. On the other hand, there was also a negative effect of temperature from the previous summer and a positive effect of precipitation in the same period (also for the year of tree-ring formation) (Danek et al. 2017, 2018). Moreover, a negative effect of drought was observed in larch locations in the Sudetes (Danek et al. 2021). It has been suggested that the much more pronounced effect of drought that is observed in larch growing in the Sudetes (compared to that of the Carpathians) could be related to climatic differences between these two mountain regions, especially considering the fact that the Sudetes are generally characterized by lower summer precipitation totals (compare Danek et al. 2018, 2021).

The above studies clearly show that larches in the Sudetes are highly sensitive to currently changing climatic factors, and extreme responses to droughts are clearly observable. Furthermore, the Sudetes are a region in which changes in climatic trends are relatively strong. Therefore, Sudetes larches seem to be a good testbed for the study of temporal changes in growth responses to climatic forcing. To assess 
these changes, a climate-growth relationship analysis over time was performed together with clustering, change-point detection and predictor importance analysis. It was specifically hypothesized that (1) the set of the most important climatic factors that influence larch tree-ring growth changes over time; (2) significant changes in larch growth response to particular factors have occurred recently; (3) the pattern of these changes is related to altitude; (4) there is a temporal connection between changes in climatic factors trends and tree-ring growth responses.

\section{Materials and methods}

\section{Study location characteristics}

The Sudetes are a mid-altitude mountain range in Central Europe on the border of Poland and the Czech Republic, and they stretch for about $300 \mathrm{~km}$ from NW to SE. It is a relatively old mountain massif (the main phases of its folding took place in the Hercynian orogeny); it has a complex structure and lithology and is built of various rocks (mainly metamorphic and magmatic) of Precambrian to Quaternary age. Together with selective long-term denudation, up- and downfaulting in the late Cenozoic period are well reflected in the diverse morphology of this region (Migoń and Placek 2014). The general outline of the Sudetes consists of rectangular and rhomboid-shaped massifs (from about $700 \mathrm{~m}$ to $1603 \mathrm{~m}$ a.s.l.), and intermontane basins that vary in shape and size (Migoń 2011).

As is typical of the mountains of this part of Europe, the Sudetes are characterized by a decrease in temperature and an increase in precipitation with altitude. In the Karkonosze range, which is the largest and highest massif of the Sudetes, the temperature gradient is on average $0.6{ }^{\circ} \mathrm{C} / 100 \mathrm{~m}$; the annual precipitation ranges from $950 \mathrm{~mm} /$ year (in the Karkonosze foothills) to $1400 \mathrm{~mm} /$ year (in the most upper parts; Raj and Knapik 2014). It should be added that the amount of precipitation in the lower locations is much smaller, especially in the mountain basins (600-700 mm/year; Walczak 1968). An increase in altitude is accompanied by a shortening of the growing season, the lengthening of snow cover duration, and increased intensity of solar radiation and wind speed (Walczak 1968). Apart from altitude, other topoclimatic factors (e.g., distance from the Atlantic Ocean, latitude, landform features and their exposure to air masses) affect the spatial pattern of climatic conditions in the area (Walczak 1968; Ojrzyńska 2015). The warmest month of the year is July, which is also the month with the highest precipitation. The coldest month is January, while the least amount of precipitation is recorded in February. Recently observed climate warming in the Sudetes is mainly characterized by a considerable increase in air temperature and the intensification of thermal extremes (Głowicki 2008). For Karkonosze, climate warming is especially reflected in the increasing trend of the sum of active temperatures of values $>5{ }^{\circ} \mathrm{C}$ and a shortening of the thermal winter. In addition, there is evidence of increasing frequency of droughts and episodes of extremely high air temperatures (Dubicka and Głowicki 2000). The number of frosty and very frosty days is decreasing for the entire elevation profile of the Sudetes, while the number of warm and hot days is increasing in mountain basins and lower parts of the mountains (Głowicki 2008; Graczyk et al. 2017).

\section{Dendrochronological data}

In this study, 21 larch site chronologies from different parts of the Sudetes were used. The site locations were in the foothill zone, the lower ranges of the western and eastern part of the Sudetes, as well as the most distinct and highest massif, Karkonosze, which is located in the center (Fig. 1). The altitudinal range of sites was from 325 to $930 \mathrm{~m}$ a.s.l. Most of the sites represent the mountain mixed fresh forest type (classification of Polish forests according to Matuszkiewicz 1978) and grow mostly on cambisols and arenosols. Larch in the study area grows in mixed stands of open to moderate canopy closure, mainly with spruce and beech. The mean diameter of larches varied from 38 to $65 \mathrm{~cm}$; the mean height varied from 26 and $34 \mathrm{~m}$. 14-20 larch trees of a similar age were sampled at each site (usually, two cores were taken per tree, parallel to the slope). Detailed characteristics of the study locations are included in Danek et al. (2018). Correlated and dated tree-ring series from trees sampled at each site were used to create site chronologies, which were constructed using double detrending (i.e., with the application of an exponent or simple regression in the first stage of standardization, and a cubic smoothing spline with a $50 \%$ frequency response cut-off which was equal to two-thirds of the series length in the second stage). Residual versions of the constructed chronologies, which are commonly used in climate-growth relationship analysis (Fritts 1976; Coppola et al. 2012; Lebourgeois et al. 2012), were used in the next stages of analysis. The constructed chronologies have good signal strength, as indicated by the relatively high mean inter-series correlation values (the mean Rbar for the indexed tree-ring series varied from 0.39 to 0.61 ) and Expressed Population Signal values (EPS, 0.93-0.98). The values of mean sensitivity, which is an indicator of the presence of high-frequency variance, were moderate $(0.19-0.3)$ in the context of the usefulness of chronologies in dendroclimatological studies (cf. Grissino-Mayer 2001). More details on the construction of the chronologies and their statistical characteristics are included in Danek et al (2018). 


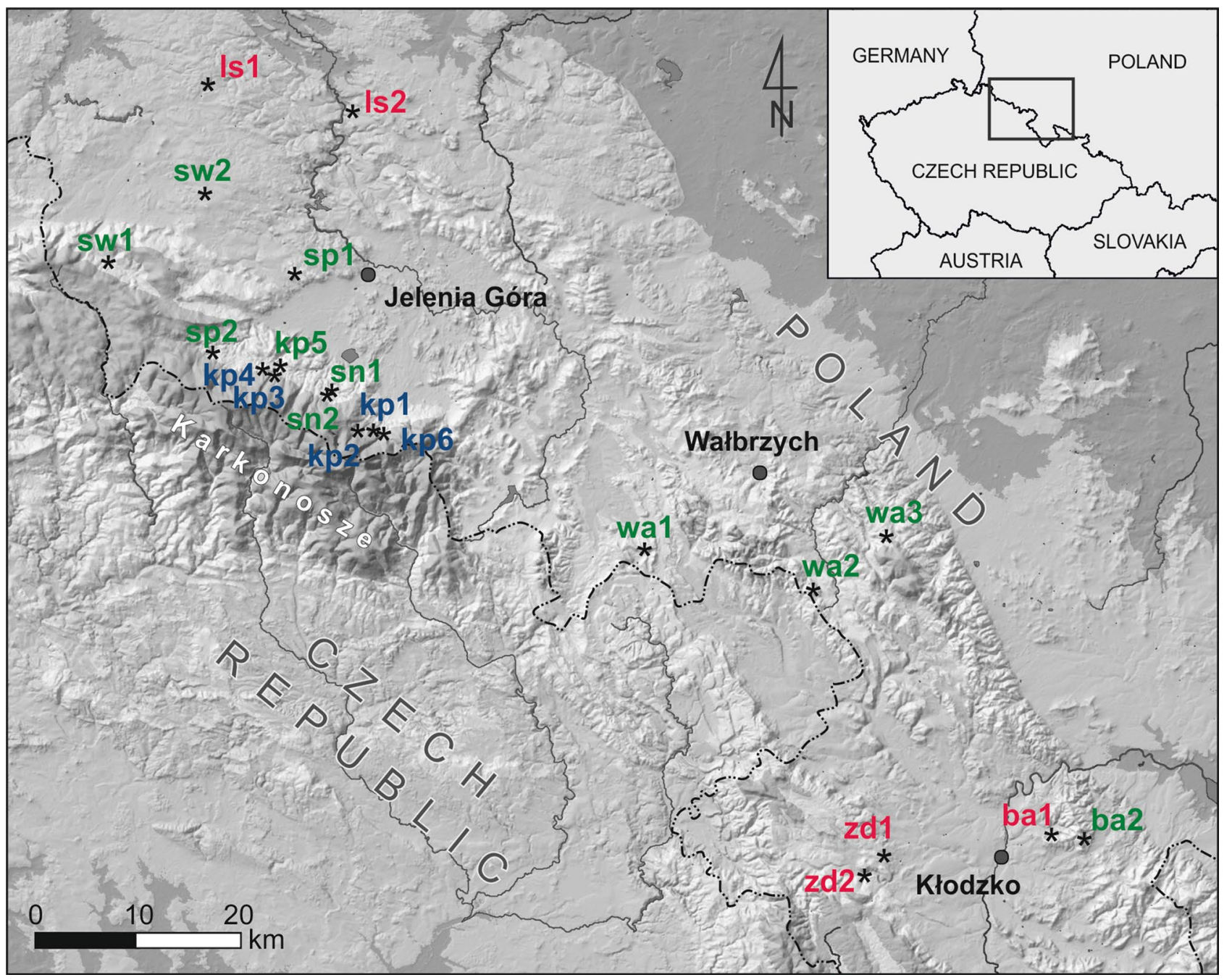

Fig. 1 Study area and site locations. Black stars represent the site locations. Colors of the sites' names correspond to the distinguished clusters: red—cluster $\mathrm{C} 1$ (mean altitude $412 \mathrm{~m}$ a.s.1.); blue-C2 (mean altitude $837 \mathrm{~m}$ a.s.1.); green-C3 (mean altitude $587.5 \mathrm{~m}$ a.s.1.)

\section{Climate data}

This study used CRU TS 4.04 climate data from the Climate Research Unit (Harris et al. 2014). These data are available in a $0.5 \times 0.5$ degree grid and cover the entire common period, i.e., the period covered by all chronologies (1925-2010). CRU data show a high degree of similarity to local meteorological station data (Chuchro and Danek 2017, 2018) but have a wider time span. Average monthly temperatures, monthly precipitation totals, and PET (potential evapotranspiration) data were used. Distance-weighted averages of the three nearest grid points were used to obtain approximated values of climatic variables at the exact positions of the sites. PET and precipitation data were also used to calculate SPEI (Standardized Precipitation-Evapotranspiration Index; Vincente-Serrano et al. 2010) using R's SPEI package (Beguería and Vicente-Serrano 2017). SPEI is a drought index that is based on precipitation and PET (Vincente-Serrano et al. 2010). The advantage over other indices of using SPEI (e.g., SPI) is that, in addition to precipitation, it also takes into account temperature through evapotranspiration information. An additional advantage is that it uses relatively straightforward calculations (in contrast to PDSI). We calculated 1-month SPEI to analyze the effects of meteorological droughts (Mishra and Singh 2010; Pei et al. 2020).

\section{Data analysis}

For each chronology, analysis of the climate-growth relationship over time was performed using DENDROCLIM2002 (Biondi and Waikul 2004). The moving-correlation (MC) coefficients were calculated in a 34-year moving window. The period from May of the year preceding tree-ring growth 
to September of the year of tree-ring formation was analyzed; this resulted in 17 predictors for each climatic variable (temperature, precipitation, and SPEI). This analysis was performed to obtain a pattern of temporal changes in the larch tree-ring growth response to climatic factors. The climate-growth relationship analysis for the common period (1925-2010) that was carried out by Danek et al. (2018) identified the set of factors that have a highly significant effect on tree-ring growth. For the year preceding tree-ring formation, these factors were the temperature in June, July, August, and November, the precipitation in July, and the SPEI of July and August. In the year of tree-ring formation, these factors were the temperature, precipitation, and the SPEI in May and July. Our interpretation was mainly focused on these factors, but the possible effect of the remaining predictors was also checked.

To generalize larch growth response to climate throughout the study area and possibly obtain spatial and/or altitudinal patterns, we performed cluster analysis of all site chronologies in the common period. We applied hierarchical agglomerative clustering using Ward's method with Euclidean distance.

We also performed change-point analysis (Bhattacharya 1994) for selected climatic variables to find the possible connection between changes in these variables and treering growth responses over time. As a model, we used a piecewise linear function, whose number of segments was determined using AICc (Akaike Information Criterion corrected for small sample size) (Hurvich and Tsai 1989). This criterion was used because models in which the number of samples divided by the number of model parameters is relatively low $(<40)$ were considered (Burnham and Anderson 2002). In all calculations, R's "segmented" package was used (Muggeo 2003, 2008).

Finally, to assess the importance of climatic variables, Random Forest (RF) regression (Breiman 2001) was performed for two periods, 1925-1967 and 1968-2010, which correspond to the first and second half of the common period. The RF approach, which has already been applied in similar studies (Prasad et al. 2006; Jevšenak et al. 2018), was employed here as it provides an efficient tool for analysis of the importance of correlated predictors (Strobl et al. 2008). RF methods perform well when the number of observations is very low compared to the number of predictors (even an order of magnitude lower in so-called "small $\mathrm{n}$ large $\mathrm{p}$ problems"). In general, RF methods are an extension of the Decision Tree method (Breiman et al. 1984), with the addition of two-level randomization. The first randomization is achieved by building many decision trees on bootstrapped data. This operation is called "bagging" and aims to limit variance and improve the quality of prediction by aggregating results from many trees. The second randomization concerns variables. Each time a decision tree creates a new branch, only a random subset of predictors is taken into consideration. These features make RF a very efficient tool for building complicated models whose main goal is not prediction (or classification) but rather selection of the most informative parameters. In its classic form, the predictor importance calculation is based on averages of squared differences between single-tree predictions and the real values of observations omitted in the creation of a particular decision tree with applied weights. Strobl et al. (2008) identified that this approach is biased towards correlated predictors due to the preference of these predictors in the tree building process and by the unconditional permutation scheme that is used in the classic form of the variable importance measure calculation. By applying functions from R's "party" package, they proposed a conditional permutation approach to obtain the unbiased importance measure that is used in this study (Horthorn et al. 2006; Strobl et al. 2007, 2008).

\section{Results}

\section{Clustering and moving window correlation analysis}

The results of the hierarchical cluster analysis indicate that the altitude factor seems to be responsible for the division of the chronologies into clusters (Fig. 2): cluster C1 is made up of site chronologies from the lowest altitudes (325-499 $\mathrm{m}$ a.s.1.), while cluster $\mathrm{C} 2$ consists of the highest sites (744-930 $\mathrm{m}$ a.s.1.). C3, which is the biggest cluster, is built from site chronologies located at medium altitudes (469-706 $\mathrm{m}$ a.s.1.). The results of the MC analysis showed high variability in tree-ring responses to climatic factors in the analyzed period. Among the climatic factors that have

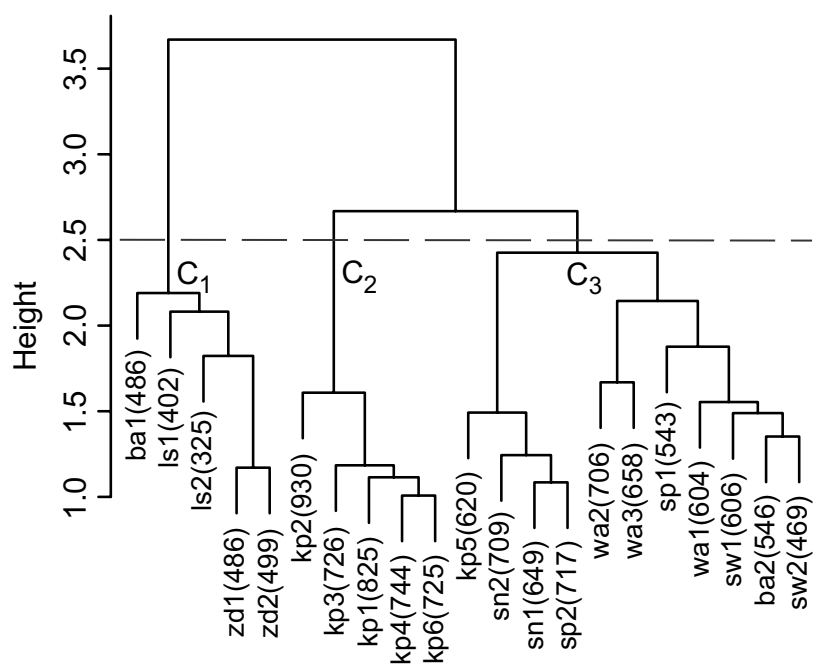

Fig. 2 Results of clustering analysis with distinguished clusters (C1C3) marked. Site altitudes ( $m$ a.s.l.) in brackets after site names 
the greatest influence on tree-ring growth in the study area (Danek et al. 2018), the most distinct temporal changes in MC values were obtained for the May temperature of the year of tree-ring formation, as well as July SPEI, thermo-pluvial conditions during the summer months of the year preceding growth (i.e., July and August), and the
November temperature for the year previous to growth. Results for all clusters are presented in Fig. 3.

For the previous July temperature, the obtained results are generally stable in the clusters representing higher sites (cluster C2 and C3, Fig. 3a), with the only noticeable change being the complete absence of positive $\mathrm{MC}$ values in the early 1960s. However, for the lower sites (cluster
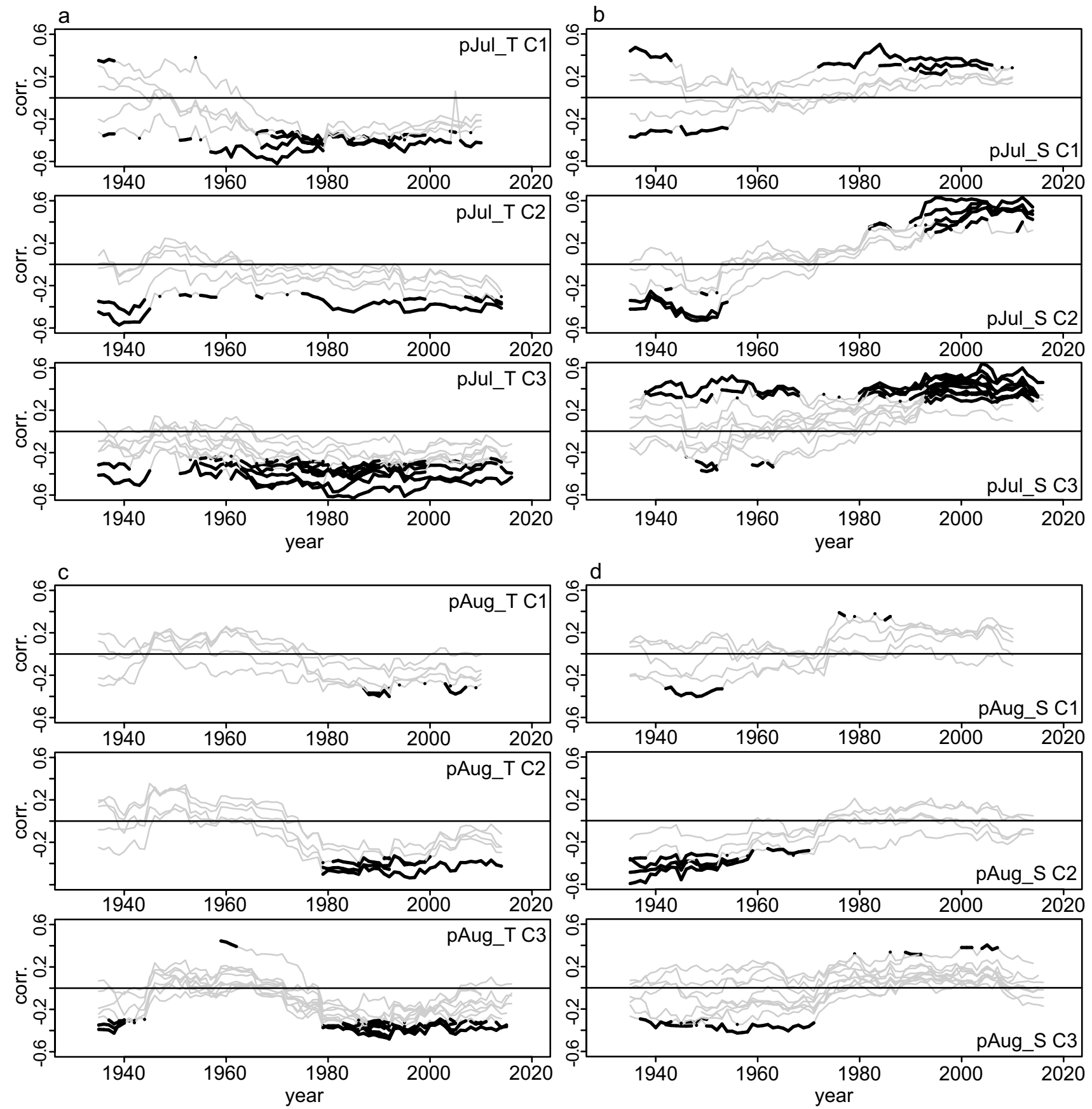

Fig. 3 Moving-window correlation coefficients between residual versions of site chronologies and selected climatic factors (window length: 34 years). $\mathrm{T}$-average monthly temperature; $\mathrm{S}$-1-month SPEI; $p$ before month name denotes the previous year; $\mathrm{C} 1-\mathrm{C} 3$ denote distinguished clusters (e.g., pJul_T C1: previous July temperature, cluster $\mathrm{C} 1$ ). Bold lines represent statistically significant values (confidence level 0.95) 

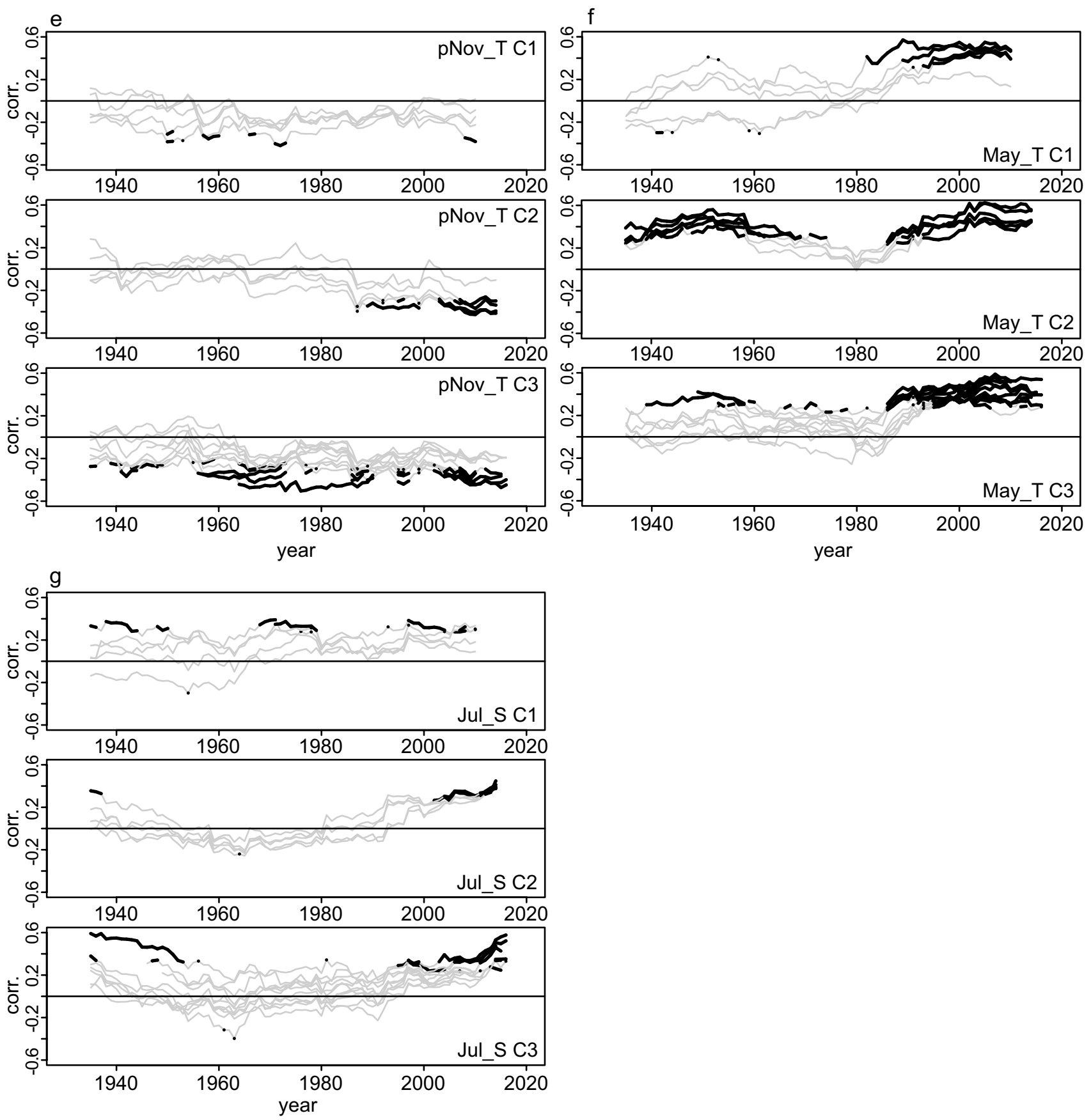

Fig. 3 (continued)

C1), a clear increase in the synchronization of MC values is observable in the 1970s, together with an increase in negative MC values (Fig. 3a). For the previous July's SPEI, the shift in correlation values is prominent. Whereas the results are rather diverse (with only a limited number of significant correlations) in the first part of the analyzed period, there is a distinct increase in the number of statistically significant correlations, with all values being positive in the more contemporary period (Fig. 3b). The increase in the synchronization of results for the whole study area is striking: particularly noteworthy is the shift from negative to positive SPEI values for the highest sites (C2). Results for precipitation are very similar to SPEI (and therefore not presented).

For the August temperature of the previous year, there is a shift from positive (but mainly low) to negative MC values for the most recent analyzed period (Fig. 3c). Significant MC values are most numerous in the 1980s and 1990s. 
Also noteworthy is the change in observed $\mathrm{MC}$ values in the 1940s (a correlation increase) and the late 1970s (a decrease) for all sites. For the SPEI of this month, MC values are only significant (and negative) at the beginning of analyzed period, and almost only for mountain sites (C2 and C3). Later, the significance of SPEI (and precipitation) practically disappeared throughout the whole area (Fig. 3d).

The last analyzed month of the year prior to tree-ring formation is November. The most pronounced change occurred for the highest sites (cluster $\mathrm{C} 2$ ): in the most contemporary period (after 2005), four of the five sites in this cluster started to show significant negative MC values for temperature, whereas significant values were not observed at all before the mid-1980s (Fig. 3e). A similar effect is observed for cluster $\mathrm{C} 3$, but here significant values were also observed earlier to a greater or lesser extent. In cluster $\mathrm{C} 1$, there are almost no significant correlations.

The results of the analysis show that the temperature in May is a factor of great importance, especially in the most recent period. Significant MC values are observed for almost all chronologies (Fig. 3f). At the same time, the observed MC values were subject to prominent changes over time: they are strongest for the $\mathrm{C} 2$ cluster, where they are also most stable, but there was a marked decline in values in the middle period (1960s to early 1980s). It is also important to note that the results in this cluster are consistent throughout the analyzed period. For all clusters, an increase in correlation values began in the middle of the 1980s; almost all observed $\mathrm{MC}$ values are significant, and the coherence of the results clearly increases (Fig. 3f).

The correlation results for July SPEI also show a recent increase in synchronization of MC values across all clusters, with almost complete unification for cluster $\mathrm{C} 2$ (Fig. 3g). In clusters $\mathrm{C} 2$ and $\mathrm{C} 3$, a clear increase in MC values is observable, as well as a gradual increase in the number of statistically significant correlations (in the last years of the analysis, this reaches $100 \%$ of sites).

The results obtained for the other climatic variables are available as supplementary materials.

\section{Change-point analysis}

Next, we focused on the variability in the months in which the greatest changes in correlation coefficients occurred over time, i.e., May, July, August, and November. Because climate change in the study area is reflected in an increase in air temperature and changes in precipitation are mostly not significant (cf. "Introduction"), we only focused on this climatic variable. The change-point analysis for May and July produced very consistent results for all locations, and AICc supports only one change point for all of them (Fig. 4a,b). There was a clear upward trend that occurred in the mid-1970s for May and in the mid-1980s for July. The calculated confidence intervals are relatively wide, which is typical of a switch from a horizontal to an upward trend (Fig. 4a, b). These are narrower for July as growth is stronger in this month (Fig. 4b). Change-point analysis of August temperatures shows a sharp decline in temperature in the 1950s, which continued into the 1960s in mountain locations. AICc indicates the occurrence of two change points in all but three locations (Fig. 4c). Generally, an increasing trend has been recorded since the 1960s. The highest number of detected change points is observed in November, where the results are not as uniform as those obtained for the other analyzed months. However, from the mid-1990s, temperatures are characterized by a sharp, well-defined increase that is recorded for all locations (Fig. 4d).

\section{The importance of predictors}

To check the importance of particular predictors such as temperature and precipitation, we used the Random Forest (RF) approach, which takes into consideration the possible collinearity of predictors (Strobl et al. 2008). To aggregate the responses in particular clusters $(\mathrm{C} 1, \mathrm{C} 2$, and $\mathrm{C} 3)$, Principal Component Analysis was performed. In all three cases, we obtained only one eigenvalue higher than 1 , so only one component from each cluster was used (Kaiser-Guttman criterion; Kaiser 1960). These components explained $67 \%, 80 \%$, and $60 \%$ of the variance in the $\mathrm{C} 1, \mathrm{C} 2$, and $\mathrm{C} 3$ clusters, respectively. The results obtained for the two considered periods (1925-1967 and 1968-2010) are presented in Fig. 5. The importance values were rescaled to 100 . In all cases, the eight most important predictors are presented. Because the results of the RF predictor importance analysis can occasionally vary between independent runs, all calculations were repeated ten times. For the more important predictors, the observed differences were rather small and were limited to the order of predictors, which showed very similar relative importance values. As expected, the order of the least important predictors, i.e., those with an importance ranked lower than 5 , was random. In all runs, $R^{2}$ values were always around 0.7 . Figure 5 shows the results with the highest $R^{2}$ values. May temperature is the most important predictor for all clusters in the second analyzed period, while in the first period this was the second most important predictor for the highest cluster only (C2) (Fig. 5). It seems that the importance of precipitation is limited to the year preceding tree-ring formation. The exception is August precipitation in the $\mathrm{C} 2$ cluster for the first period, in which it was the most important predictor.

\section{Discussion}

Cluster analysis shows that the lowest sites are clearly separated (cluster $\mathrm{C} 1$, mean altitude $412 \mathrm{~m}$ a.s.l.). Furthermore, the highest sites ( $\mathrm{C} 2$, mean altitude $837 \mathrm{~m}$ a.s.l.) are 

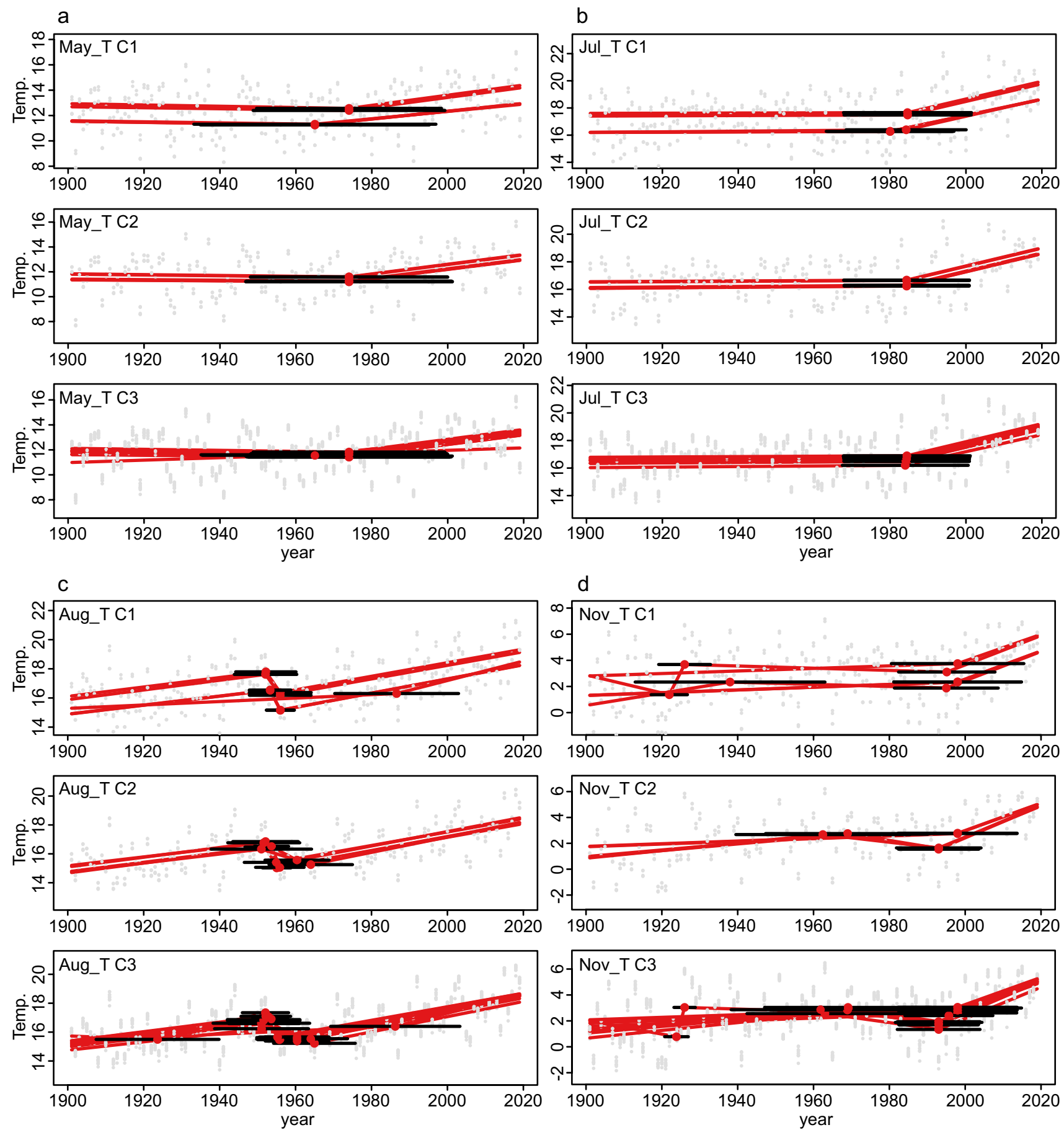

Fig. 4 Change-point analysis results for monthly average temperature values (May (a), July (b), August (c), and November (d)) in the distinguished clusters $(\mathrm{C} 1-\mathrm{C} 3)$. Grey dots represent temperature data;

red dots—-determined change points; red lines—-determined trends. Horizontal black bars show confidence intervals (confidence level $0.95)$

distinguished from slightly lower ones (C3, mean altitude $587.5 \mathrm{~m}$ a.s.1.; Fig. 2). This suggests that altitude was the main factor differentiating larch growth in the study area, which corresponds to the results of Danek et al. (2018), where PC1 explained variance increases with altitude. The results of $\mathrm{MC}$ analysis also show that the pattern of temporal

changes is different between these altitude-based clusters, but the differences seem to disappear recently.

Previous climate-growth relationship analysis performed for the Sudetes in the whole common period indicated May temperature as an important factor (Danek et al. 2018). Similar responses were recorded for larch in neighboring 

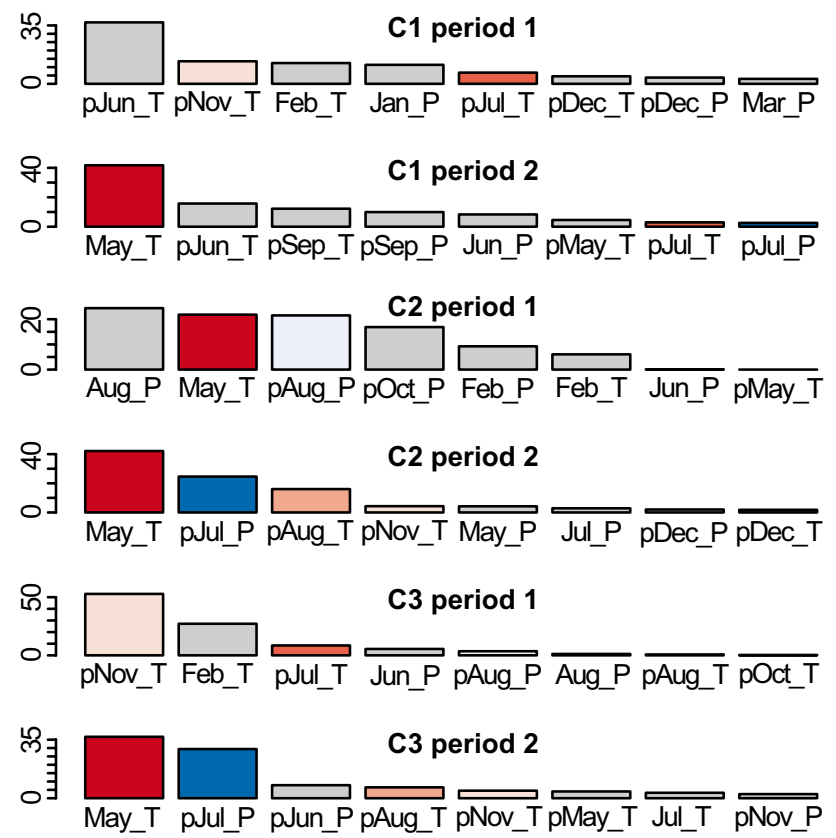

Fig. 5 Random forest predictor importance obtained for each cluster (C1-C3) in period 1 (1925-1967) and period 2 (1968-2010). Colors indicate the climatic factors discussed: red indicates temperature; blue indicates precipitation. In-bar labels: T-average monthly temperature; $\mathrm{P}$-monthly precipitation total; $\mathrm{p}$ before month name denotes previous year (e.g., pJun_T: previous Jun temperature)

parts of the Carpathians and the lowlands (Ermich 1955; Büntgen et al. 2007; Danek et al. 2017; Koprowski 2012; Vitas 2015). The results of MC analysis show that the treering growth/May temperature relationship has only become common in the Sudetes since the mid-1980s (Fig. 3f). The growing importance of May temperature is confirmed by RF predictor importance analysis, where in the more recent period (1968-2010) it becomes the most important predictor for all clusters (Fig. 5). Mid-May is the period that has seen the strongest warming over Central and Western Europe (Pokorná et al. 2018). For the Sudetes, the most significant rate of increase of daily mean maximum temperature values was observed for May $\left(0.6^{\circ} \mathrm{C} / 10\right.$ years; Głowicki 2008). The change point from no trend to an upward trend for May in the study area occurred in the mid-1970s (Fig. 4a), which is about a decade before the observed increase in the number of significant MC values. Please note that the length of the correlation window is 34 years, and the results are assigned to the most recent year. The increased importance of May temperature has also been observed in the Tatra Mountains in the second half of the twentieth century (Konter et al. 2015). Positive trends in correlations with this climatic factor were also recorded in the Italian Alps in the twentieth century (Carrer and Urbinati 2006; Coppola et al. 2012). For the Sudetes area, these trends were also observed for spruce (Treml et al. 2012). On the other hand, recent studies of young larches (less than 50 years old) from Poland have shown no significant impact of May temperature on treering width in recent decades (Wilczyński and Kulej 2013; Szymański and Wilczyński 2021). This lack of significant response of young trees may be caused by age-dependent sensitivity to climatic factors (Carrer and Urbinati 2004).

The relationship between tree-ring growth and May temperature is stronger and more stable over time in the highest locations (cluster C2). This may be explained by the more temperature-related growth of conifers at higher altitudes (e.g., Frank and Esper 2005; Leal et al. 2007). However, even in this cluster, there has been a clear increase in the role of this climatic factor more recently, as May temperature moves from second to first position in the results of RF importance analysis (Fig. 5). The described correlation is not stable over time: a clear decrease in MC values occurred in the 1960s and 1970s. A similar decrease was recorded for larch in the Italian Alps in the same period (Coppola et al. 2012).

The recently observed increased importance of May temperature may be the result of an additional phenomenon that has made it influential for larch growing in all locations in the Sudetes. In relation to the recently observed climate warming and temperature increase (Menzel and Fabian 1999), the lengthening of the growing season may change the climate-growth relationship of trees (Fischer and Neuwirth 2013). A connection between the lengthening duration of the growing season and changes in the sensitivity of trees to certain climatic factors is suggested by the authors of the aforementioned studies (Carrer and Urbinati 2006; Coppola et al. 2012; Treml et al. 2012; Konter et al. 2015), which concern high-altitude spruce and larch stands. Lengthening of the growing season manifests primarily as an earlier onset of spring (Chmielewski and Rötzer 2001; Menzel et al. 2006; Linderholm 2006). Increased temperatures early in the growing season may cause the earlier onset of cambium activity and xylem differentiation (compare Rossi et al. 2007; Begum et al. 2018; Saderi et al. 2019). This may also come into play for lower sites, where water availability is usually an important limiting factor for growth. During the spring months, water resources are still relatively high. Therefore, the positive effects of higher temperatures on tree growth (although still not as high as in summer) are not yet limited by drought. It is also possible that there is a shift of the main growing season towards the earlier part of the year, when water availability is guaranteed (Konter et al. 2015). This shift may be beneficial as there may be a shortening of the active growing season due to the increasingly limited period between winter and the hot, dry summer (Trnka et al. 2011). This may be related to the findings of Cabon et al. (2020): temperature is the main factor responsible for the onset of wood production, whereas water potential and temperature constrain the end and the annual amount of wood 
production. Additionally, drought in the summer may cause premature cessation of radial growth (Pichler and Oberhuber 2007; Saderi et al. 2019).

Water availability in the growing season seems to be the main factor responsible for the observed changes in larch response in the summer months. For July temperature, an upward trend since the 1980s is observed (Fig. 4b). This probably explains the increase in MC values between annual growth and July SPEI that can be observed in recent years (Fig. 3g). The observed rise is prominent for the higher sites (clusters C2 and C3). This may suggest that the larch's demand for water is increasing; at the same time, it indicates that water shortages are occurring, especially at higher elevations where water deficit was not a problem before. The larch is very sensitive to drought (Eilmann and Rigling 2012; Lévesque et al. 2013, 2014), which is related to its anisohydric behavior (Anfodillo et al. 1998; Leo et al. 2014) and annual foliage production (Eilmann and Rigling 2012). Tree water deficit (a measure of water stress) depends more on air temperature than precipitation or soil water content (Oberhuber et al. 2015). Furthermore, as the temperature increases, the water pressure deficit increases exponentially (Breshears et al. 2013). It should also be added that, in the study of Cabon et al. (2020) on larch and fir in the Swiss Alps, water potential was found to be the main factor responsible for the tracheid production rate during summer. All these phenomena provide a good explanation for the recently observed increase in correlation with the SPEI, thus indicating the critical importance of water availability for larch growth during the summer season.

Previous analysis of larch growth in the Sudetes has indicated that temperature and moisture conditions of the summer of the previous year are more important than those of the summer of the year in which the tree ring is formed (Danek et al. 2018, 2021). The negative influence of previous summer temperatures on larch growth, and in many cases a strong connection between growth and water availability in that period, was also found in other nearby areas of Europe (Oleksyn and Fritts 1991; Koprowski 2012; Vitas and Žeimavičius 2010; Lévesque et al. 2014; Vitas 2015; Jansons et al. 2015; Danek et al. 2017). This can be explained by the lagged effect of decreased carbohydrate reserves caused by high temperatures, thus affecting respiration, bud formation, and fruit set (Oleksyn and Fritts 1991). On the other hand, favorable conditions in previous summers (i.e., lower temperatures and sufficient water availability) can increase carbohydrate reserves, thus positively influencing growth in the next year (compare Lévesque et al. 2014).

In recent years, an increase in the negative effect of the previous July and August temperature can be observed. For the SPEI, these months' responses differentiate over time. For the previous July, a clear shift from insignificant or negative to coherent and strongly positive correlations can be observed (Fig. 3b). In the following month, the almost complete disappearance of the response significance of SPEI can be seen (Fig. 3d). This may suggest that water conditions for the previous July have recently been more important for larch growth. For higher sites (clusters C2 and C3), previous July precipitation is (after May temperature) the most important predictor of growth in the more contemporary period (Fig. 5). Moreover, for the highest sites (cluster C2), the predictive importance of precipitation in the preceding August disappears; instead, the importance of precipitation in the previous July emerges as a factor (Fig. 5), which may suggest a shift in larch growing activity in the highest sites.

The results show that the water demands of larch in the study area are not being met, thus making the conditions of both the summer of tree-ring formation and of the previous summer significant limiting factors for larch growth, regardless of altitude. This is supported by the observed increased synchronization in larch response to climatic factors all over the area, which is particularly pronounced for July temperature and SPEI, where synchronization is almost as strong as for May temperature (Fig. 3a, b, g). A similar effect of synchronization increases was observed by Latte et al. (2015), who explained increasing inter-site synchronization in beech tree-ring growth by an increase in its climate sensitivity in response to the more frequent warming-related intense droughts and heat waves in recent decades.

For November, the observed negative response to temperature has been getting stronger since the beginning of twenty-first century (Fig. 3e). This unification can be associated with the rapid increase in temperature that occurred in the second half of the 1990s and is visible in change-point results (Fig. 4d). This is in agreement with the large rise in November temperature observed in meteorological station data for the whole of Poland (Wójcik and Miętus 2014). The negative effect of higher temperatures in this month may be related to the need for late-autumn chilling. High temperatures on short days cause effective bud dormancy that results in delayed and irregular bud burst in the spring (Simak 1970; Heide 2003), which in consequence may indirectly affect tree growth (compare Danek et al. 2018). The lack of a response in the lowest cluster may be explained by the delayed onset of the required chilling to the following month as a steep downward trend toward negative MC values is observed for December (for figures, please see supplementary materials).

\section{Conclusions}

The study shows temporal changes in the growth response of larch in the Polish Sudetes to climatic factors that affect its growth. Moreover, the study indicates that the response of larch to dominant climatic factors has recently become 
uniform throughout the whole area, regardless of altitude, which seems to be the main factor differentiating the climatic responses of larch in the Polish Sudetes. An increasingly positive effect of May temperature can be observed. The study also indicates a progressive negative influence of temperature in the summer and late autumn of the year preceding growth, and an increasing positive relationship with SPEI during the summer (especially in July of the year in which the tree ring is formed, and the previous July and August). The most dynamic change can be observed in larch from the highest elevations, where the relationship with the previous July's SPEI has changed from negative to positive over the last century. The analysis indicates a connection with recent climate change, which in the study area is mostly expressed by a relatively rapid rise in temperatures, which in consequence has a negative influence on water availability. The change of larch responses to climatic factors may also suggest a shift and a shortening of the larch growing season. Considering the sensitivity of larch to drought (Eilmann and Rigling 2012), the results presented here, along with the predicted increase in temperatures and thermal extremes and the decrease of the share of summer precipitation in the annual total (Wypych et al. 2017; Graczyk et al. 2017; Szwed 2019), suggest its growth in the Sudetes will be very limited. It may also lead to an increase in its mortality.

Author contribution statement MD conceived the ideas, collected and processed the data, contributed in data analysis, and wrote the paper. TD contributed in conceiving the ideas, data collection and analysis, and paper writing.

Supplementary Information The online version contains supplementary material available at https://doi.org/10.1007/s00468-021-02251-3.

Acknowledgements The authors would like to thank the staff of the Regional Directorate of State Forests in Wroclaw (RDLP Wroclaw), local forest districts, and Karkonosze National Park for their support and help during the fieldwork. The authors thank Joanna Świąder for technical support.

Funding This study was supported by the National Science Centre, Poland (project No. 2014/13/B/ST10/02529) and by the AGH University of Science and Technology as part of the statutory project of the Faculty of Geology, Geophysics and Environmental Protection. Research project was also partly supported by program "Excellence initiative-research university" for the AGH University of Science and Technology.

Availability of data and materials The datasets generated and used during the current study are available from the corresponding author on reasonable request.

\section{Declarations}

Conflict of interest The authors declare that they have no conflict of interest.

Ethics approval Not applicable.

Consent to participate Not applicable.

Consent for publication Not applicable.

Open Access This article is licensed under a Creative Commons Attribution 4.0 International License, which permits use, sharing, adaptation, distribution and reproduction in any medium or format, as long as you give appropriate credit to the original author(s) and the source, provide a link to the Creative Commons licence, and indicate if changes were made. The images or other third party material in this article are included in the article's Creative Commons licence, unless indicated otherwise in a credit line to the material. If material is not included in the article's Creative Commons licence and your intended use is not permitted by statutory regulation or exceeds the permitted use, you will need to obtain permission directly from the copyright holder. To view a copy of this licence, visit http://creativecommons.org/licenses/by/4.0/.

\section{References}

Allen CD, Macalady AK, Chenchouni H, Bachelet D, McDowell N, Vennetier M, Kitzberger T, Rigling A, Breshears DD, Hogg EH, Gonzalez P, Fensham R, Zhang Z, Castro J, Demidova N, Lim J-H, Allard G, Running SW, Semerci A, Cobb N (2010) A global overview of drought and heat induced tree mortality reveals emerging climate change risks for forests. For Ecol Manag 259:660-684

Anfodillo T, Rento S, Carraro V, Furlanetto L, Urbinati C, Carrer M (1998) Tree water relations and climatic variations at the alpine timberline: seasonal changes of sap flux and xylem water potential in Larix decidua Miller, Picea abies (L.) Karst. and Pinus cembra L. Ann for Sci 55:159-172

Babst F, Poulter B, Trouet V, Tan K, Neuwirth B, Wilson R, Carrer M, Grabner M, Tegel W, Levanic T, Panayotov M, Urbinati C, Bouriaud O, Ciais P, Frank D (2013) Site- and species-specific responses of forest growth to climate across the European continent. Glob Ecol Biogeogr 22:706-717

Beguería S, Vicente-Serrano SM (2017) SPEI: calculation of the standardised precipitation-evapotranspiration index. $\mathrm{R}$ package version 1.7. https://CRAN.R-project.org/package=SPEI

Begum S, Kudo K, Rahman MH, Nakaba S, Yamagishi Y, Nabeshima E, Nugroho WD, Oribe Y, Kitin P, Jin H-O, Funada F (2018) Climate change and the regulation of wood formation in trees by temperature. Trees 32:3-15. https://doi.org/10.1007/ s00468-017-1587-6

Beniston M (2003) Climatic change in mountain regions: a review of possible impacts. Clim Chang 59:5-31

Bhattacharya P (1994) Some aspects of change-point analysis. Lecture Notes-Monograph Series 23:28-56

Biondi F, Waikul K (2004) DENDROCLIM 2002: a C++ program for statistical calibration of climate signals in tree-ring chronologies. Comput Geosci 30:303-311

Błażejczyk K (2019) Sezonowa i wieloletnia zmienność niektórych elementów klimatu w Tatrach i Karkonoszach w latach 19512015 [Seasonal and multiannual variability of selected elements 
of climate in the Tatra and Karkonosze Mts over the 1951-2015 period]. Prz Geogr 91(1):41-62

Breiman L (2001) Random forests. Mach Learn 45:5-32

Breiman L, Friedman JH, OlshenR SC (1984) Classification and regression trees. Routledge. https://doi.org/10.1201/9781315139 470

Breshears DD, Adams HD, Eamus D, McDowell NG, Law DJ, Will RE, Williams AP, Zou CB (2013) The critical amplifying role of increasing atmospheric moisture demand on tree mortality and associated regional die-off. Front Plant Sci 4:266. https://doi.org/ 10.3389/fpls.2013.00266

Briffa KR, Schweingruber FH, Jones PD, Osborn TJ, Harris IC, Shiyatov SG, Vaganov EA, Grudd H, Cowie J (1998) Trees tell of past climates: but are they speaking less clearly today? Philos Trans R Soc B Biol Sci 353:65-73

Büntgen U, Frank DC, Kaczka RJ, Verstege A, Zwijacz-Kozica T, Esper J (2007) Growth responses to climate in a multi-species tree-ring network in the Western Carpathian Tatra Mountains, Poland and Slovakia. Tree Physiol 27:689-702

Burnham KP, Anderson DR (2002) Model selection and multimodel inference: a practical information-theoretic approach, 2nd edn. Springer-Verlag, New York

Cabon A, Peters RL, Fonti P, Martínez-Vilalta J, De Cáceres M (2020) Temperature and water potential co-limit stem cambial activity along a steep elevational gradient. New Phytol 226:1325-1340. https://doi.org/10.1111/nph.16456

Carrer M, Urbinati C (2004) Age-dependent tree-ring growth response to climate in Larix decidua and Pinus cembra. Ecology 85:730-740

Carrer M, Urbinati C (2006) Long-term change in the sensitivity of tree-ring growth to climate forcing in Larix decidua. New Phytol 170:861-872

Chmielewski F-M, Rötzer T (2001) Response of tree phenology to climate change across Europe. Agric for Meteorol 108:101-112

Chuchro M, Danek M (2017) Applicability of gridded climate data in tree-ring studies of larch from southern part of Poland. In: Proceedings of the SGEM 2017: Water resources, forest, marine and ocean ecosystem, Vol 17, no 32, pp 717-725

Chuchro M, Danek M (2018) Selection of optimal gridded dataset for application in Polish Sudetes Mountains. IOP Conf Ser Earth Environ Sci 221:012120

Coppola A, Leonelli G, Salvatore M, Pelfini M, Baroni C (2012) Weakening climatic signal since mid-20th century in European larch tree-ring chronologies at different altitudes from the AdamelloPresanella Massif (Italian Alps). Quat Res 77(3):344-354. https://doi.org/10.1016/j.yqres.2012.01.004

Dale VH, Joyce LA, McNulty S, Neilson RP, Ayres MP, Flannigan MD, Hanson PJ, Irland LC, Lugo AE, Peterson CJ et al (2001) Climate change and forest disturbances. Bioscience 51:723-734

Danek M, Chuchro M, Walanus A (2017) Variability in larch (Larix decidua Mill.) tree-ring growth response to climate in the Polish Carpathian Mountains. Forests 8(10):354. https://doi.org/10. 3390/f8100354

Danek M, Chuchro M, Walanus A (2018) Tree-ring growth of larch (Larix decidua Mill.) in the Polish Sudetes-the influence of altitude and site-related factors on the climate-growth relationship. Forests 9:663. https://doi.org/10.3390/f9110663

Danek M, Chuchro M, Danek T (2021) Extreme growth reaction of larch (Larix decidua Mill.) from the Polish Sudetes and Carpathians: spatial distribution and climate impact. Trees 35:211-229. https://doi.org/10.1007/s00468-020-02029-z

Driscoll WW, Wiles GC, D'Arrigo RD, Wilmking M (2005) Divergent tree growth response to recent climatic warming, Lake Clark National Park and Preserve. Alaska Geophys Res Lett 32:L20703

Du Q, Rossi S, Lu X, Wang Y, Zhu H, Liang E, Camarero JJ (2020) Negative growth responses to temperature of sympatric species converge under warming conditions on the southeastern Tibetan Plateau. Trees 34:395-404. https://doi.org/10.1007/ s00468-019-01924-4

Dubicka M, Głowicki B (2000) Ekoklimat Karkonoszy w przekroju wieloletnim w świetle wskaźników kompleksowych [A longterm view on the ecoclimate of the Karkonosze Mountains in the light of complex indices]. Opera Corcon 37:55-61

Dyderski MK, Paź S, Frelich LE, Jagodziński AM (2018) How much does climate change threaten European forest tree species distributions? Glob Chang Biol 24:1150-1163

Eilmann B, Rigling A (2012) Tree-growth analyses to estimate tree species' drought tolerance. Tree Physiol 32:178-187

Einspahr DW, Wyckoff GW, Fiscus MH (1984) Larch—a fast-growing fiber source for the Lake States and Northeast. J for 82:104-106. https://doi.org/10.1093/jof/82.2.104

Ermich K (1955) Zależność przyrostu drzew w Tatrach od wahań klimatycznych [The dependence of the diameter growth of trees from Tatra mountains on the climatic fluctuations]. Acta Soc Bot Pol 24:245-273

Fischer S, Neuwirth B (2013) Vulnerability of trees to climate events in temperate forests of West Germany. ISRN For 2013, Article ID 201360, pp 15

Frank D, Esper J (2005) Characterization and climate response patterns of a high-elevation, multi-species tree-ring network in the European Alps. Dendrochronologia 22:107-121

Friedrichs DA, Trouet V, Büntgen U, Frank DC, Esper J, Neuwirth B, Löffler J (2009) Species-specific climate sensitivity of tree growth in Central-West Germany. Trees 23:729-739

Fritts HC (1976) Tree rings and climate. Academic Press, London

García-Cervigón AI, Olano JM, Eugenio-Gozablo M, Camarero JJ (2012) Arboreal and prostrate conifers coexisting in Mediterranean high mountains differ in their climatic responses. Dendrochronologia 30:279-286

Głowicki B (2008) Ekstremalne zjawiska termiczne w Sudetach w okresie współczesnych zmian klimatu [Extreme thermal phenomena in the sudetes in the period of contemporary climatic changes]. Infrastruktura i Ekologia Terenów Wiejskich/infrastruct Ecol Rural Areas 8:29-40

Gottfried M, Pauli H, Futschik A, Akhalkatsi M, Barančok P, Alonso B, Luis J, Coldea G, Dick J, Erschbamer B, Calzado F, Rosa M, Kazakis G, Krajči J, Larsson P, Mallaun M, Michelsen O, Moiseev D, Moiseev P, Molau U, Merzouki A, Nagy L, Nakhutsrishvili G, Pedersen B, Pelino G, Puscas M, Rossi G, Stanisci A, Theurillat J-P, Tomaselli M, Villar L, Vittoz P, Vogiatzakis I, Grabherr G (2012) Continent-wide response of mountain vegetation to climate change. Nat Clim Change 2:5. https://doi.org/10. 1038/nclimate1329

Graczyk D, Pińskwar I, Kundzewicz ZW, Hov Ø, Førland EJ, Szwed M, Choryński A (2017) The heat goes on-changes in indices of hot extremes in Poland. Theor Appl Climatol 129:459-471. https://doi.org/10.1007/s00704-016-1786-x

Grissino-Mayer HD (2001) Evaluating crossdating accuracy: a manual and tutorial for the computer program COFECHA. Tree Ring Res 57:205-221

Hanewinkel M, Cullmann DA, Schelhaas M-J, Nabuurs GJ, Zimmermann NE (2013) Climate change may cause severe loss in the economic value of European forest land. Nat Clim Change 3:203-207

Harris I, Jones PD, Osborn TJ, Lister DH (2014) Updated high-resolution grids of monthly climatic observations - the CRU TS3.10 Dataset. Int J Climatol 34(3):623-642

Hartmann DL, Klein Tank AMG, Rusticucci M, Alexander LV, Dronnimann S, Charabi Y, Dentener FJ, Dlugokencky EJ, Easterling DR, Kaplan A, Soden BJ, Thorne PW, Wild M, Zhai PM (2013) Observations: atmosphere and surface. In: Stocker TF, Qin D, Plattner G-K, Tignor M, Allen SK, Boschung J, Nauels A, Xia 
Y, Bex V, Midgley PM (eds) Climate change 2013. The physical science basis. Working Group I contribution to the fifth assessment report of the intergovernmental panel on climate change. Cambridge University Press, Cambridge, pp 159-254

Heide OM (2003) High autumn temperature delays spring bud burst in boreal trees, counterbalancing the effect of climatic warming. Tree Physiol 23:931-936

Hothorn T, Buehlmann P, Dudoit S, Molinaro A, Van Der Laan M (2006) Survival ensembles. Biostatistics 7(3):355-373

Hurvich CM, Tsai C-L (1989) Regression and time series model selection in small samples. Biometrika 76:297-307

Jagodziński AM, Dyderski MK, Gęsikiewicz K, Horodecki P (2018) Tree- and stand-level biomass estimation in a Larix decidua Mill. chronosequences. Forests 9:587. https://doi.org/10.3390/f9100 587

Jansons Ā, Matisons R, Purina L, Neimane U, Jansons J (2015) Relationships between climatic variables and tree-ring width of European beech and European larch growing outside of their natural distribution area. Silva Fenn 49(1):1255

Jevšenak J, Džeroski S, Zavadlav S, Levanič T (2018) A Machine learning approach to analyzing the relationship between temperatures and multi-proxy tree-ring records. Tree Ring Res 74(2):210-224. https://doi.org/10.3959/1536-1098-74.2.210

Ji F, Wu Z, Huang J, Chassignet EP (2014) Evolution of land surface air temperature trend. Nat Clim Change 4(6):462-466. https:// doi.org/10.1038/nclimate2223

Jolly WM, Dobbertin M, Zimmermann NE, Reichstein M (2005) Divergent vegetation growth responses to the 2003 heat wave in the Swiss Alps. Geophys Res Lett 32(18):L18409

Kaiser HF (1960) The application of electronic computers to factor analysis. Educ Psychol Meas 20(1):141-151. https://doi.org/ 10.1177/001316446002000116

Kolář T, Čermák P, Trnka M, Žid T, Rybníček M (2017) Temporal changes in the climate sensitivity of Norway spruce and European beech along an elevation gradient in Central Europe. Agric for Meteorol 239:24-33. https://doi.org/10.1016/j.agrfo rmet.2017.02.028

Konter O, Rosner K, Kyncl T, Esper J, Büntgen U (2015) Spatiotemporal variations in the climatic response of Larix decidua from the Slovakian Tatra Mountains. In: Wilson RM, Helle G, Gärtner H (eds) TRACE—-tree rings in archaeology, climatology and ecology, Vol 13. Scientific Technical Report 15/06, GFZ German Research Centre for Geosciences, pp 62-68

Koprowski M (2012) Long-term increase of March temperature has no negative impact on tree rings of European larch (Larix decidua) in lowland Poland. Trees 26:1895-1903

Krzysik F (1978) Nauka o drewnie. Wyd. Naukowe PWN, Warszawa

Łabędzki L, Kanecka-Geszke E, Bąk B, Słowińska S (2011) Estimation of reference evapotranspiration using the FAO Penman-Monteith method for climatic conditions of Poland. In: Łabędzki L (ed) Evapotranspiration. InTechOpen, London, pp 275-294

Latte N, Lebourgeois F, Claessens H (2015) Increased tree-growth synchronization of beech (Fagus sylvatica L.) in response to climate change in northwestern Europe. Dendrochronologia 33:69-77

Leal S, Melvin TM, Grabner M, Wimmer R, Briffa KR (2007) Tree ring-growth variability in the Austrian Alps: the influence of site, altitude, tree species and climate. Boreas 36:426-440

Lebourgeois F, Mérian P, Courdier F, Ladier J, Dreyfus P (2012) Instability of climate signal in tree-ring width in Mediterranean mountains: a multi-species analysis. Trees 26:715-729. https:// doi.org/10.1007/s00468-011-0638-7

Leo M, Oberhuber W, Schuster R, Grams TEE, Matyssek R, Wieser G (2014) Evaluating the effect of plant water availability on inner alpine coniferous trees based on sap flow measurements. Eur $\mathrm{J}$ for Res 133:691-698. https://doi.org/10.1007/s10342-013-0697-y
Lévesque M, Saurer M, Siegwolf R, Eilmann B, Brang P, Bugmann H, Rigling A (2013) Drought response of five conifer species under contrasting water availability suggests high vulnerability of Norway spruce and European larch. Glob Chang Biol 19(10):31843199. https://doi.org/10.1111/gcb.12268 (Epub 2013 Aug 10)

Lévesque M, Rigling A, Bugmann H, Weber P, Peter Brang P (2014) Growth response of five co-occurring conifers to drought across a wide climatic gradient in Central Europe. Agric for Meteorol 197:1-12. https://doi.org/10.1016/j.agrformet.2014.06.001

Linderholm HW (2006) Growing season changes in the last century. Agric for Meteorol 137(1-2):1-14. https://doi.org/10.1016/j. agrformet.2006.03.006

Lindner M, Maroschek M, Netherer S, Kremer A, Barbati A, GarciaGonzalo J, Seidl R, Delzon S, Corona P, Kolström M, Lexer MJ, Marchetti M (2010) Climate change impacts, adaptive capacity, and vulnerability of European forest ecosystems. For Ecol Manag 259:698-709

Lindner M, Fitzgerald JB, Zimmermann NE, Reyer C, Delzon S, van der Maaten E, Schelhaas M-J, Lasch P, Eggers J, van der Maaten-Theunissen M, Suckow F, Psomas A, Poulter B, Hanewinkel M (2014) Climate change and European forests: what do we know, what are the uncertainties, and what are the implications for forest management? J Environ Manag 146:69-83

Lu X, Camarero JJ, Liang E (2021) Threshold responses of juniper tree growth and regeneration to climate warming and drought stress at alpine treeline. Trees 35:1081-1083. https://doi.org/ 10.1007/s00468-021-02135-6

Lyu S, Wang X, Zhang Y, Li Z (2017) Different responses of Korean pine (Pinus koraiensis) and Mongolia oak (Quercus mongol$i c a)$ growth to recent climate warming in northeast China. Dendrochronologia 45:113-122. https://doi.org/10.1016/j.dendro. 2017.08.002

Mäkinen H, Nöjd P, Kahle HP, Neumann U, Tveite B, Mielikäinen K, Röhle H, Spiecker H (2002) Radial growth variation of Norway spruce (Picea abies (L.) Karst.) across latitudinal and altitudinal gradients in central and northern Europe. For Ecol Manag 171:243-259

Matuszkiewicz W (1978) Fitosocjologiczne podstawy typologii lasów Polski [Phytosociological basics of typology of Polish forests]. Pr Inst Badaw Leśn 558:3-39

McDowell N, Pockman WT, Allen CD, Breshears DD, Cobb N, Kolb T, Plaut J, Sperry J, West A, Williams DG, Yepez EA (2008) Mechanisms of plant survival and mortality during drought: why do some plants survive while others succumb to drought? New Phytol 178:719-739. https://doi.org/10.1111/j.1469-8137. 2008.02436.x

Menzel A, Fabian P (1999) Growing season extended in Europe. Nature 397:659

Menzel A, Sparks TH, Estrella N, Koch E, Aasa A, Ahas R, AlmKübler K, Bissolli P, Braslavská O, Briede A, Chmielewski F-M, Crepinsek Z, Curnel Y, Dahl A, Defila C, Donnelly A, Filella Y, Jatczak K, Måge F, Mestre A, Nordli Ø, Peñuelas J, Pirinen P, Remišová V, Scheifinger H, Striz M, Susnik A, van Vliet AJH, Wielgolaski F-E, Zach S, Zust A (2006) European phenological response to climate change matches the warming pattern. Glob Chang Biol 12(10):1969-1976

Migon P (2011) Geomorphic diversity of the Sudetes-effects of structure and global change superimposed. Geog Pol 84(Special Issue Part 2):93-105

Migon P, Placek A (2014) Lithological and structural control on the relief of the Sudetes. Prz Geol 64:36-43

Mishra AK, Singh VP (2010) A review of drought concepts. J Hydrol 391:202-216

Muggeo VMR (2003) Estimating regression models with unknown break-points. Stat Med 22:3055-3071 
Muggeo VMR (2008) segmented: an R package to fit regression models with broken-line relationships. $\mathrm{R}$ News 8/1: 20-25. https://cran.r-project.org/doc/Rnews/

Oberhuber W, Kofler W, Schuster R, Wieser G (2015) Environmental effects on stem water deficit in co-occurring conifers exposed to soil dryness. Int J Biometeorol 59:417-426. https://doi.org/ 10.1007/s00484-014-0853-1

Ojrzyńska H (2015) Cyrkulacyjne uwarunkowania przestrzennego rozkładu temperatury powietrza na terenie zróżnicowanym morfologicznie na przykładzie Sudetów [Circulation conditionings of spatial differentiation of air temperature in morphologically diverse area with the Western Sudeten as an example]. Rozprawy Naukowe Instytutu Geografii i Rozwoju Regionalnego Uniwersytetu Wrocławskiego 36, Wrocław

Oleksyn J, Fritts HC (1991) Influence of climatic factors upon tree rings of Larix decidua and L. decidua x L. kaempferi from Puławy. Poland Trees 5:75-82

Pei Z, Fang S, Wang L, Yang W (2020) Comparative Analysis of Drought Indicated by the SPI and SPEI at Various Timescales in Inner Mongolia, China. Water 12(7):1925. https://doi.org/10. 3390/w12071925

Pichler P, Oberhuber W (2007) Radial growth response of coniferous forest trees in an inner Alpine environment to heat-wave in 2003. For Ecol Manag 242(2-3):688-699. https://doi.org/10. 1016/j.foreco.2007.02.007

Pokorná L, Kučerová M, Huth R (2018) Annual cycle of temperature trends in Europe, 1961-2000. Glob Planet Change 170:146-162. https://doi.org/10.1016/j.gloplacha.2018.08.015

Ponocná T, Spyt B, Kaczka R, Büntgen U, Treml V (2016) Growth trends and climate responses of Norway spruce along elevational gradients in East-Central Europe. Trees 30(5):1633-1646. https://doi.org/10.1007/s00468-016-1396-3

Prasad AM, Iverson LR, Liaw A (2006) Newer classification and regression tree techniques: bagging and random forests for ecological prediction. Ecosystems 9(2):181-199. https://doi.org/10. 1007/s10021-005-0054-1

Raj A., Knapik R (2014) Karkonoski Park Narodowy. II wydanie [Karkonosze National Park. II edition]. Karkonoski Park Narodowy, Jelenia Góra

Rigling A, Bigler C, Eilmann B, Feldmeyer-Christe E, Gimmi U, Ginzler C, Graf U, Mayer P, Vacchiano G, Weber P, Wohlgemuth T, Zweifel R, Dobbertin M (2013) Driving factors of a vegetation shift from Scots pine to pubescent oak in dry Alpine forests. Glob Chang Biol 19(1):229-240. https://doi.org/10.1111/gcb.12038

Rossi S, Deslauriers A, Anfodillo T, Carraro V (2007) Evidence of threshold temperatures for xylogenesis in conifers at high altitudes. Oecologia 152:1-12

Rozenberg P, Chauvin T, Escobar-Sandoval M, Huard F, Shishov V, Charpentier J, Sergent A, Vargas-Hernandez JJ, MartinezMeier A, Pâques L (2020) Climate warming differently affects Larix decidua ring formation at each end of a French Alps elevational gradient. Ann for Sci 77:54. https://doi.org/10.1007/ s13595-020-00958-w

Saderi S, Rathgeber CBK, Rozenberg P, Fournier M (2019) Phenology of wood formation in larch (Larix decidua Mill.) trees growing along a 1000-m elevation gradient in the French Southern Alps. Ann for Sci 76:89

Simak M (1970) Photo- and thermoperiodic responses of different larch provenances (Larix decidua Mill.). Stud for Suec 86:1-31

Spiecker H (1999) Overview of recent growth trends in European forests. Water Air Soil Pollut 116:33-46

Strobl C, Boulesteix A-L, Zeileis A, Hothorn T (2007) Bias in random forest variable importance measures: illustrations. Sources Solut BMC Bioinform 8:25
Strobl C, Boulesteix A-L, Kneib T, Augustin T, Zeileis A (2008) Conditional variable importance for random forests. BMC Bioinform 9:307. https://doi.org/10.1186/1471-2105-9-307

Szwed M (2019) Variability of precipitation in Poland under climate change. Theor Appl Climatol 135(3-4):1003-1015

Szymański N, Wilczyński S (2021) Radial growth response of European larch provenances to interannual climate variation in Poland. Forests 12:334. https://doi.org/10.3390/f12030334

Teskey R, Wertin T, Bauweraerts I, Ameye M, McGuire MA, Steppe K (2015) Responses of tree species to heat waves and extreme heat events. Plant Cell Environ 38(9):1699-1712

Tessier L, Guibal F, Schweingruber FH (1997) Research strategies in dendroecology and dendroclimatology in mountain environments. Clim Chang 36:499-517

Thompson I, Mackey B, McNulty S, Mosseler A (2009) Forest resilience, biodiversity, and climate change. A synthesis of the biodiversity/resilience/stability relationship in forest ecosystems. Secretariat of the Convention on Biological Diversity, Technical Series, 43, Montreal, pp 1-67

Tomczyk AM, Bednorz E (2016) Heat waves in Central Europe and their circulation conditions. Int J Climatol 36:770-782. https:// doi.org/10.1002/joc.4381

Treml V, Ponocná T, Büntgen U (2012) Growth trends and temperature responses of treeline Norway spruce in the Czech-Polish Sudetes Mountains. Clim Res 55:91-103

Trnka M, Olesen JE, Kersebaum KC, Skjelvåg AO, Eitzinger J, Seguin B, Peltonen-Sainio P, Rötter R, Iglesias A, Orlandini S, Dubrovský M, Hlavinka P, Balek J, Eckersten H, Cloppet E, Calanca P, Gobin A, Vučetić V, Nejedlik P, Kumar S, Lalic B, Mestre A, Rossi F, Kozyra J, Alexandrov V, Semerádová D, Žalud Z (2011) Agroclimatic conditions in Europe under climate change. Glob Chang Biol 17(7):2298-2318

Vicente-Serrano SM, Beguería S, López-Moreno JI (2010) A multiscalar drought index sensitive to global warming: the Standardized Precipitation Evapotranspiration Index-SPEI. J Clim 23:1696-1718

Villalba R, Boninsegna JA, Veblen TT, Schmelter A, Rubulis S (1997) Recent trends in tree-ring records from high elevation sites in the Andes of Northern Patagonia. In: Diaz HF, Beniston M, Bradley RS (eds) Climatic change at high elevation sites. Springer, Dordrecht. https://doi.org/10.1007/978-94-015-8905-5_11

Vitas A (2015) A dendroclimatological analysis of European larch (Larix decidua Mill.) from Lithuania. Balt for 20:65-72

Vitas A, Žeimavičius K (2010) Regional tree-ring chronology of European larch (Larix decidua Mill.) in Lithuania. Balt for 16(2):187-193

Walczak W (1968) Dolny Śląsk. Cz. I-Sudety [Lower Silesia. Part I-the Sudetes]. Wydawnictwo Naukowe PWN, Warszawa

Wilczyński SB, Kulej M (2013) The influence of climate on the radial increment of larches of different provenances on the basis of the experiment in the Carpathian Mountains in Southern Poland. Eur J for Res 132:919-929. https://doi.org/10.1007/ s10342-013-0731-0

Wójcik R, Miętus M (2014) Niektóre cechy wieloletniej zmienności temperatury powietrza w Polsce (1951-2010) [Some features of long-term variability in air temperature in Poland (1951-2010)]. Prz Geogr 86(3):339-364

Wypych A, Sulikowska A, Ustrnul Z, Czekierda D (2017) Temporal variability of summer temperature extremes in Poland. Atmosphere 8:51

Ziernicka-Wojtaszek A, Kopcińska J (2020) Variation in atmospheric precipitation in Poland in the years 2001-2018. Atmosphere 11:794. https://doi.org/10.3390/atmos11080794

Publisher's Note Springer Nature remains neutral with regard to jurisdictional claims in published maps and institutional affiliations. 